\title{
CHALLENGE BASED LEARNING: AN EDUCATIONAL PROPOSAL FOR SOCIAL TRANSFORMATION
}

\author{
Mariano Sánchez Cuevas \\ Vice presidency for academic affairs, UPAEP University (México)
}

\begin{abstract}
The approach of problematic situations in the educational process requires the incorporation of new teaching and learning methodologies, among which the Challenge Based Learning (CBL) is presented as a pedagogical proposal to favor the development of transversal and disciplinary competences, collaborative work, leadership, research, critical and reflective thinking. The CBL allows the involvement of students in real teaching contexts, so that, through the design and implementation of projects, they generate proposals for solving the main social challenges; this teaching dynamic is based on the theory of experiential learning. The present work describes the antecedents, characteristics, the stages for the development of the CBL, and its main differences with the Problem Based Learning (PBL) and the Project Based Learning. Finally, the stages of the CBL are exemplified with a university experience of implementation of the project called Social Reconstruction, which allowed the participation of students and professors in a multidisciplinary and collaborative way in the social transformation of two Mexican communities affected by the earthquake of September 19, 2017.
\end{abstract}

Keywords: Experiential learning, challenge based learning, social transformation.

\section{Introduction}

New educational trends suggest the use of active methodologies in teaching and learning, centered in the student in order to favor the analysis and design of proposals for solving the main challenges of society. Among the methodologies, the Challenge Based Learning (CBL) is proposed, this method was originated in 2008 in a project by Apple company called Apple Classrooms of Tomorrow-Today.

CBL, as a pedagogical proposal, is based on experiential learning which incentives students to raise solutions to several problems, related with their environment, through their immersion in real training contexts and the design of multidisciplinary intervention projects. Under these contexts, learners recognize a problem of their own interest, and this issue becomes for them a challenge to be approached, analyzed, discussed and solved in a methodologically and collaboratively way. In addition to the above, the CBL awakens in the students a sensitivity about local problems that most affect society; favoring the development of various competences; for example: problem solving, communication skills, research, use of technology, collegial thinking, emotional competences, analytical thinking, reflective thinking and social commitment (Nichols et al., 2016).

Under the CBL, students have the opportunity to recognize the relevance of contents they have learned in the classroom through their active, intellectual, creative, social and emotional involvement in projects of global significance with local actions in order to solve those problems in a critical and proactive way. In fact, students are being directly involved in the context of the problem to be solved. However, it should be noted that the development of problem solving competence is not typical of the CBL, since this is similar to Problem Based Learning (PBL) and Project Learning (PL). The CBL, unlike the first one, uses real scenarios for the problematization of the contents while in the PBL the simulation of the problems is allowed (Sánchez, 2016), and with respect to its relation with the PL, the design of integrating projects is one of the characteristics that they share. However, in the CBL it is essential that the designed project be implemented, evaluated and disseminated. 


\section{CBL methodology}

CBL begins with the approach of the general topic to be worked with, and that is called in this method like the Great Idea. During this phase, the teacher, as a facilitator of the process, together with the students, define the topic of global relevance and the possibilities of local action to work with. In this first stage, the essential question of the process is also established, and this is characterized by set a general question which allows linking the issue to be addressed with the problem to be solved (Apple, 2011).

Subsequently, students, once selected the challenge they wish to attend, they establish a series of important questions to work with in their research process. It is a key element, at the moment of defining the challenge, students closeness inside the problem environment because the above not only sensitize them about the neediness of social transformation, but also will allow them to dimension the needs to be solved, the actions to be established, and the possible scope of his intervention.

With the sustenance of the research, a systematized planning of the key activities is carried out. The necessary resources are also defined to address the challenge; through a dynamic group sessions of students with the guidance of their teacher. The purpose of this phase is that, through research, activities and collaborative work sessions, students will have sufficient knowledge to be able to generate innovative solution proposals for the selected challenge.

The next phase of this methodology consists of a construction of the solution proposal to the stablished challenge. That is how this proposal is described through the design of an intervention project. The project considers a multidisciplinary vision of the solution, as well as its concretion in several tangible deliverables which are developed during the implementation of the project. The foregoing makes this possible in order to demonstrate both, the acquired learning and the competences developed by the students. They, without a doubt, add this to their formative educational process, oriented towards social transformation.

Finally, the mechanisms to evaluate the learning and the impact of the project are established and also how the strategies for disseminating the results obtained are presented. The evaluation process requires the selection of the strategies and instruments necessary for the collection and recording of the information that is generated in the different phases planned. With regard to dissemination, students with the support of their teacher, agree on the best way to share the experience lived with both, the recipients of the project, and the academic community. This last stage makes it possible to identify the progress in the fulfillment of the expected objectives, achievements and the learning acquired by students and, it allows as well to appreciate the impact on transformation of reality in the community served.

The reflection and the informative evaluation are one important part of the process in each stage since they reinforce the learning and prepare the learners for similar situations in their professional future.

\section{Social reconstruction project}

In order to exemplify the CBL process, the experience of UPAEP is described below, whose educational model U-50 proposes an educational vision that mobilizes and transforms society from the person itself, through the generation of significant experiences through the use of active methodologies in teaching and learning processes; seeking, in this way, the formation of transformative leaders of social realities.

This university experience with CBL had as main purpose to involve both, students and professors, collaboratively and multidisciplinary, in a social intervention project, generated from the conjuncture of the earthquake of September 19th, 2017 in Mexico, which it brought housing destruction in rural communities.

The following describes the actions carried out by the project called Social Reconstruction, considering the stages of the CBL (Table 1). 
Table 1. University experience of CBL employment.

\begin{tabular}{|c|c|}
\hline Great Idea & Social Reconstruction \\
\hline Main question & $\begin{array}{l}\text { How could the university would help to rebuild the } \\
\text { communities affected by the earthquake? }\end{array}$ \\
\hline Definition of the challenge & $\begin{array}{l}\text { Rebuild the communities of Tepapayeca, } \\
\text { municipality of Tlapanala and San Francisco } \\
\text { Xochiteopan, municipality of Atzizihuacán, both } \\
\text { in the State of Puebla. }\end{array}$ \\
\hline UPAEP participants & $\begin{array}{l}\text { Students and professors from the Faculties of } \\
\text { Medicine, Nutrition, Architecture, Civil } \\
\text { Engineering and Environmental Engineering } \\
\text { High School students of the UPAEP. } \\
\text { University Life Area } \\
\text { Humanist Training Area and Entrepreneurs. }\end{array}$ \\
\hline Strategic allies & $\begin{array}{l}\text { Puebla Community Foundation, Estrella Roja, } \\
\text { Mapfre Foundation and Beck Foundation. }\end{array}$ \\
\hline Activities performed & $\begin{array}{l}\text { Installation of a university gathering center } \\
\text { Visit to the communities of Tepapayeca and } \\
\text { Xochiteopan to size the problem and define the } \\
\text { needs to be addressed. } \\
\text { Brigades that supply provisions, help with } \\
\text { demolition and debris removal. } \\
\text { Diagnoses of health and nutritional status. } \\
\text { Community integration activities with families, } \\
\text { children and youth. } \\
\text { Proposals for architectural designs. } \\
\text { Establishment of strategies for educational, } \\
\text { cultural, family and community strengthening. } \\
\text { Advice in the process of economic reactivation. }\end{array}$ \\
\hline Evaluation & $\begin{array}{l}\text { Preparation of evidences of the intervention } \\
\text { through photographs and videos. In the same way, } \\
\text { interviews and feedback sessions were held with } \\
\text { the students, professors and representatives of the } \\
\text { communities through the methodology of focus } \\
\text { groups. }\end{array}$ \\
\hline Divulgation & $\begin{array}{l}\text { Advances and results obtained during the project } \\
\text { were shared with the university community and } \\
\text { with the inhabitants of the affected communities, } \\
\text { through internal means of communication and } \\
\text { follow-up visits. } \\
\text { There are portfolios of evidences prepared by the } \\
\text { students. }\end{array}$ \\
\hline
\end{tabular}

\section{Conclusions}

The incorporation of innovative pedagogical strategies in the educational process, as a response to the need for an integral formation in university students, requires the establishment of systematized, collaborative and multidisciplinary educational actions which allows the linking of the disciplinary contents with the main social challenges.

The experience with the Social Reconstruction Project, under the CBL method, allowed university students and professors not only to become aware of the current problems of the communities affected by the earthquake, but also to participate directly in the various activities derived from the project. So, students will be favored with transversal, disciplinary and professional competences.

Teachers, students and the UPAEP community with the incorporation of the CBL, in their pedagogical model, have had the opportunity to concretize their educational proposal through the generation of integrative projects of community intervention and with actions linked to various agents of change, such as it is the instances of government, organisms and foundations of the civil society and companies. This is how, it has been possible to influence the transformation of our social reality. 


\section{References}

Apple (2011). Challenge Based Learning A Classroom Guide. Retrieved from https://images.apple.com/education/docs/CBL_Classroom_Guide_Jan_2011.pdf

Nichols, M., Cator, K., Torres, M. (2016). Challenge Based Learner User Guide. Redwood City, CA: Digital Promise. Retrieved from http://cbl.digitalpromise.org/wpcontent/uploads/sites/7/2016/10/CBL_Guide2016.pdf

Sánchez, M. (2016). Aprendizaje Basado en Problemas: fundamentos, aplicación y experiencias en el aula. Primera Edición, Editorial Médica Panamericana. México. 